\title{
Prevalence of hepatitis $C$ virus infection among HIV-infected people in Casablanca
}

\author{
L Badaoui ${ }^{*}$, G Dabo, R Bensghir, M Sodqi, L Marih, A Oulad Lahsen, A Chakib, K El Filali Marhoum \\ From International Symposium HIV and Emerging Infectious Diseases 2014 \\ Marseille, France. 21-23 May 2013
}

\section{Introduction}

HIV/HCV coinfection may have important implications for therapeutic and evolving plans. The Knowledge of its epidemiological, clinical features may help to anticipate needs and improve care. The aim of the Study was to determine the epidemic profile of patients co- infected by hepatitis $\mathrm{C}$ virus and HIV.

\section{Materials and methods}

A retrospective study was conducted in the infectious department diseases between 2003 and 201 3, were included all patients treated for HIV and $\mathrm{HCV}$ with positive serology (ELISA positive). Data were collected on computer files (Nadis) and analyzed on Epi Info.

\section{Results}

We collected 147 patients with HIV/HCV coinfection ( $4 \%$ of the total workforce). The average age was $40 \pm 10$ years, males predominated $(4 \mathrm{H} / 1 \mathrm{~F})$. Intravenous drug use was found in $29.25 \%$ of patients. At the moment of diagnosis of the coinfection, 64 patients $(43.5 \%)$ were in category C (CDC) . Antiretroviral therapy was prescribed for 131 patients $(89 \%)$. The viral RNA research by RT-PCR and the genotyping were performed in 39 patients (27\%). The RNA HCV PCR was positive in 28 cases (19\%). The most frequent viral genotypes were $1 \mathrm{a}$ and $1 \mathrm{~b}$ with 14 cases $(50 \%)$. The IL28B performed in 8 patients had type CC ( 2 cases), C/T (3 cases), TT ( 1 case). Liver function tests were normal in 116 cases; liver cytolysis was found in 31 cases. The liver ultrasound was normal (80 cases) or showed lesions of chronic liver disease (30 cases) or ascites (10 cases). Ten patients undergoing treatment with pegylated interferon and ribavirin. Two patients who completed treatment were non-responders. 79 patients (54\%) are being used and 27 cases died (18\%).

University Hospital of Ibn rochd, Casablanca, Morocco

\section{Conclusion}

The HIV/HCV co-morbidity is a challenge in support of PLHIV. Currently, free access to treatment and explorations of hepatitis $C$ in Morocco as part of a health program (RAMED) is an important step whose impact needs to be evaluated.

Published: 23 May 2014

doi:10.1186/1471-2334-14-S2-P20

Cite this article as: Badaoui et al:: Prevalence of hepatitis $C$ virus

infection among HIV-infected people in Casablanca. BMC Infectious

Diseases 2014 14(Suppl 2):P20.
Submit your next manuscript to BioMed Central and take full advantage of:

- Convenient online submission

- Thorough peer review

- No space constraints or color figure charges

- Immediate publication on acceptance

- Inclusion in PubMed, CAS, Scopus and Google Scholar

- Research which is freely available for redistribution
( Biomed Central 